\title{
ANALISIS POTENSI ZAKAT PROFESI PEGAWAI NEGERI SIPIL (PNS) BAGI KEMASLAHATAN UMAT DI SUMBAWA BESAR
}

\author{
Feri Irawan ${ }^{1}$
}

\section{Abstrak}

Zakat profesi merupakan bentuk zakat baru yang muncul setelah era Nabi. Zakat profesi telah diketahui hukumnya, karena di zaman sekarang sudah banyak ulama' yang membahasnya. Zakat profesi merupakan zakat yang banyak ditemui di zaman sekarang ini. Zakat profesi diatur dalam UU No. 38 tahun 1999 tentang pengelolaan zakat. Penulis juga menyimpulkan bagaimana pemahaman para PNS dalam membayar zakat, dan apa motivasi mereka untuk membayarkan zakat profesi, serta bagaimana pola pembayarannya. Metode yang digunakan dalam penelitian ini adalah dengan pendekatan kualitatif. Jenis penelitian ini merupakan penelitian deskriptif, dengan tujuan menggambarkan bagaimana pelaksanaan pembayaran zakat profesi yang ada dalam masyarakat muslim yang berprofesi sebagai PNS di Sumbawa Besar. Pendapatan perekonomian masyarakat di zaman modern sekarang ini lebih banyak pada sektor jasa, dan yang penting memenuhi nisab. Peran $B A Z / L A Z$ diharapkan bisa menjadi wadah atau sarana yang dapat dipercaya oleh masyarakat dengan jalan lebih aktif dengan mengelola zakat serta meyakinkan masyarakat untuk membayar zakat. Penulis mengetahui begitu baiknya para PNS dalam membayarkan zakatnya, baik itu untuk menjalankan perintah Agama, melaksanakan rukun Islam, membersihkan harta, ataupun untuk sosial tolong menolong antar sesama manusia.

Kata Kunci: Zakat Profesi, Pegawai Negeri Sipil (PNS), Kemaslahatan Umat Islam

\section{Abstract}

Professional zakat is a new form of zakat that emerged after the era of the Prophets. The law of zakat on profession has been known because there are many scholars who discuss it nowadays. Zakat on profession is zakat that is commonly found today. Professional zakat is regulated in Law no. 38 of 1999 concerning zakat management. The writer concludes civil servants' perceptive in paying the zakat, their motivations to pay it, and how the payment patterns of it. The method used in this research is a qualitative approach. This type of research is a descriptive study, with the aim of describing how the implementation of the payment of professional zakat in Muslim communities who work as civil servants in Sumbawa Besar. The economic income of society in modern times is more in the service sector, and the important thing is to meet the nisab. The role of BAZ/LAZ is expected to be a forum or source that can be trusted by the community by being more active in managing zakat and convincing people to pay zakat. The writer knows that civil servants are very

${ }^{1}$ STAI Nahdlatul Wathan Samawa Sumbawa Besar-NTB,

Email: feri.irawan@stainwsamawa.ac.id 
good at paying their zakat, whether it is to carry out religious orders, accomplish the pillars of Islam, clean up property, or for social help among fellow humans.

Keywords: Professional Zakat, Civil Servants (PNS), Benefit of Muslims

\section{A. PENDAHULUAN}

Fenomena yang terjadi dalam masyarakat di dunia perekonomian modern saat ini semakin kecil keterlibatan langsung dari sumber daya manusia dalam sektor produksi dan semakin membesarnya pendapatan dari sektor jasa. Karena itu, gaji, upah, dan bonus menjadi suatu pendapatan manusia di zaman modern seperti sekarang ini, dan bernilai jauh melampaui dari nisab.

Pendapatan profesi adalah sebuah hasil dari kerja menguras otak dan keringat yang dilakukan oleh setiap orang. Contoh dari pendapatan kerja profesi adalah: gaji, upah, insentif, atau nama lainnya disesuaikan dengan jenis profesi yang dikerjakan baik itu pekerjaan yang mengandalkan kemampuan otak atau kemampuan fisik lainnya dan bahkan kedua-duanya.

Yang dapat dikategorikan dari sejumlah pendapatan yang termasuk dalam kategori zakat profesi, seperti:

1. Pendapatan dari hasil kerja pada sebuah instansi, baik pemerintah (Pegawai Negeri Sipil) maupun swasta (Perusahaan swasta). Pendapatan yang dihasilkan dari pekerjaan seperti ini biasanya bersifat aktif atau dengan kata lain relatif ada pemasukan/pendapatan pasti dengan jumlah yang relatif sama diterima secara periodik (biasanya perbulan).

2. Pendapatan dari hasil kerja profesional pada bidang pendidikan, keterampilan dan kejuruan tertentu, dimana si pekerja mengandalkan kemampuan/keterampilan pribadiannya, seperti: dokter, pengacara, tukang cukur, artis, perancang busana, tukang jahit, presenter, musisi, dan sebagainya. Pendapatan yang dihasilkan dari pekerjaan seperti ini biasanya bersifat pasif, tidak ada ketentuan pasti penerimaan pendapatan pada setiap periode tertentu. (M. Arif Mufraini, $2006: 73$ )

Hasil kerja dalam pengertian kini mencakup:

a. Gaji dan upah dan apa saja yang sehukum dengannya.

b. Upah keahlian selain perniagaan, dimana yang berperanan penting disitu ialah kerja. 
Berbeda dengan sumber pendapatan dari pertanian, peternakan dan perdagangan, sumber pendapatan dari profesi tidak banyak dikenal pada masa generasi terdahulu. Semua penghasilan melalui kegiatan profesional tersebut, apabila telah mencapai nisab, maka wajib dikeluarkan zakatnya.

Oleh karena itu pembahasan mengenai tipe zakat profesi tidak dapat dijumpai dengan tingkat kedetilan yang setara dengan tipe zakat yang lain. Namun bukan berarti pendapatan dari hasil profesi terbebas dari zakat, karena zakat secara hakikatnya adalah pungutan terhadap kekayaan golongan yang memiliki kelebihan harta untuk diberikan kepada golongan yang membutuhkan.

Dari penyaluran zakat yang penulis ketahui dari sebagian masyarakat sumbawa, penulis berpendapat bahwa zakat profesi PNS merupakan kesadaran bagi mereka yang sadar bahwa zakat sudah menjadi kewajiban bagi umat muslim, dan bukan suatu paksaan. Para PNS sesungguhnya sudah mempunyai gaji yang tetap dibandingkan dengan pekerjaan yang tidak tentu penghasilannya. Sedangkan bagi PNS yang belum bisa menyadari akan kewajiban zakat maka bisa dikatakan mereka terpaksa karena zakat tersebut sudah termasuk dalam potongan gaji yang diterima.

Disamping saat ini sudah banyak potongan gaji PNS, juga tidak jelasnya penyaluran zakatnya, maka penyerahan zakat terserah kepada muzakki (orang yang membayar zakat). Dalam hal ini pemerintah tidak berhak untuk memaksa para PNS untuk mengeluarkan zakatnya. Karena di Indonesia sendiri diketahui tidak hanya masyarakat muslim saja, tetapi banyak juga masyarakat lain yang non-muslim.

Nusa Tenggara Barat merupakan daerah strategis bagi pengembangan sosial ekonomi dan sosial keagamaan dalam upaya meningkatkan kesejahteraan masyarakat. Data statistik menunjukan jumlah penduduk Nusa tenggara Barat (NTB) 33,18 juta jiwa, jumlah rumah tangga miskin 3,1 juta keluarga dari 6,7 juta rumah tangga (46,26\%). Jumlah rumah tangga prasejahtera 3.198 .596 keluarga, dan penduduk miskin 12,66 juta jiwa. Untuk umat Islam jalan keluar bagi upaya peningkatan kesejahteraan salah satunya memaksimalkan potensi zakat. Potensi zakat di Nusa tenggara Barat (NTB) diperkirakan mencapai $\operatorname{Rp} 9,356$ triliun setiap tahun, berasal dari zakat infak dan sedekah (ZIS) Rp 8,982 trliun dan zakat fitrah Rp 374,275 miliar.(Moh Anhar dan Aris Mulyawan, 2009: 11) 
Sejak dulu, permasalahan zakat secara umum hanya terfokus kepada dua hal pokok, yakni mengenai pengelolaan dan mengenai kesadaran para wajib zakat. Untuk pengelolaan zakat sesungguhnya sudah diatur oleh UU nomor 38 tahun 1999, hanya pelaksanaannya yang masih kurang konsisten. (Muhibbin, 2009: 11)

Disini penulis beranggapan bahwa potensi zakat masyarakat Nusa tenggara Barat (NTB) begitu baik, terutama yang penulis ketahui selama turun langsung untuk melihat dan mewawancarai sebagian dari masyarakat yang PNS di Kota sumbawa, terutama di wilayah Kecamatan Sumbawa sendiri begitu baiknya mereka dalam membayarkan zakatnya, baik itu untuk menjalankan perintah agama, melaksanakan rukun Islam, membersihkan harta, ataupun untuk sosial tolong menolong antar sesama.

\section{Rumusan Penelitian}

1. Bagaimanakah pemahaman masyarakat muslim PNS di Sumbawa tentang zakat profesi?

2. Apakah motivasi masyarakat muslim PNS di Sumbawa untuk membayar atau tidak membayar zakat profesi?

3. Bagaimanakah pola pembayaran zakat profesi masyarakat muslim PNS di sumbawa?

\section{Tujuan Penelitian}

1. Penulis dapat menggali informasi mengenai pemahaman masyarakat muslim PNS di Sumbawa dalam membayar zakat profesi.

2. Penulis dapat menggali informasi tentang bagaimana motivasi para PNS di Sumbawa dalam membayar zakat profesi.

3. Penulis dapat mengetahui bagaimana pola pembayaran zakat profesi masyarakat muslim PNS di sumbawa.

\section{B. METODOLOGI PENELITIAN}

Pendekatan yang akan digunakan dalam penelitian ini adalah pendekatan kualitatif, yaitu melakukan pembahasan terhadap kenyataan atau data yang ada dalam praktek untuk selanjutnya dihubungkan dengan pendekatan secara langsung terhadap masyarakat Sumbawa yang berprofesi sebagai PNS. Jenis Penelitian ini merupakan penelitian deskriptif, sebab bertujuan untuk melukiskan 
atau memberi gambaran pelaksanaan pembayaran zakat profesi yang ada dalam masyarakat Sumbawa

Penelitian ini dilakukan pada masyarakat muslim yang berprofesi sebagai PNS yang ada di wilayah Sumbawa Besar. Peneliti lebih banyak mengambil responden dari Kecamatan Sumbawa sendiri, tepatnya di daerah panto Daeng, Kerato, dan sekitarnya, karena para PNS rata-rata adalah warga pendatang yang membeli rumah di perumahan wilayah tersebut. Jenis data yang penulis gunakan dalam penelitian ini meliputi Data Primer dan data Sekunder.

\section{PEMBAHASAN}

\section{Analisis Pemahaman Tentang Zakat Profesi}

Telah diuraikan dalam penjelasan sebelumnya bahwa penulis beranggapan kesadaran para PNS untuk membayar zakat begitu baik, meskipun dari sebagian masyarakat tidak semua mengerti tentang dasar hukum, syarat wajib, maupun penghitungan dalam penentuan zakat yang mereka keluarkan.

Zakat profesi itu bisa dilaksanakan setahun sekali, sebulan sekali, atau berapa bulan sekali, bahkan kapan saja para muzakki ingin berniat untuk membayarkan zakatnya. Meskipun zakat profesi itu sendiri sebenarnya wajib dikeluarkan jika penghasilannya, seandainya ditotal setahun setelah dikurangi kebutuhan-kebutuhannya selama setahun melebihi nisab. Jika tidak mencapai nisab, maka tidak wajib untuk dizakati.

Dari pemahaman dalam penyaluran zakat profesi yang mereka lakukan lebih banyak mereka salurkan sendiri kepada fakir miskin maupun tetangga, bahkan kepada saudara mereka sendiri yang kurang mampu. Jadi penulis beranggapan peran BAZ/LAZ sebagai badan yang dibentuk oleh pemerintah diharapkan bisa menjadi wadah atau sarana yang dapat dipercaya oleh masyarakat dengan jalan lebih aktif dengan mengelola zakat serta meyakinkan masyarakat untuk pembayaran zakat yang lebih efisien dan merata.

Pemahaman atau pengetahuan para Pegawai Negeri Sipil muslim di Salatiga sebagian dari mereka masih kurang mengetahui tentang zakat profesi dan sebenarnya ini belum sesuai dengan ajaran agama Islam, yakni kewajiban belajar atau berusaha untuk mengetahui suatu hukum Allah yang telah disyaratkan terutama ibadah yang telah 
diwajibkannya, agar ibadah itu bisa dilaksanakan secara baik dan benar sesuai dengan yang disyariatkan oleh Allah SWT.

Penulis menyimpulkan dari pemahaman tentang arti kata zakat secara bahasa yang mengandung arti suci dan tumbuh, yakni orang yang patuh membayar zakat, hatinya dididik untuk menjadi suci, sedikit demi sedikit hatinya dilatih untuk tidak terbelenggu oleh harta, serta menghilangkan sifat tamak sebagai seorang manusia, dengan memahami bahwa di dalam harta seseorang itu ada hak untuk orang lain yang harus ditunaikan dalam pembayaran zakatnya, dari pengeluaran zakat profesi para PNS muslim itu, harta mereka pun menjadi suci karena terbebas dari apa yang bukan miliknya.

\section{Analisis Motivasi Pembayaran Zakat Profesi}

Telah diuraikan dalam pembahasan sebelumnya tentang motivasi pembayaran zakat yang mereka keluarkan kepada para penerima zakat tidak hanya sesuatu penyaluran yang bersifat kewajiban pada agama saja, melainkan kewajiban kepada agama yang disertai suatu kepedulian sosial dengan maksud saling tolong menolong ( $T a^{\prime} w u n$ ) antar sesama manusia yang saling membutuhkan.

Disini penulis menyimpulkan dari penelitian yang dilakukan terhadap PNS yang ada di Sumbawa bahwa dalam pembayaran zakat profesi yang mereka keluarkan, baik itu setiap bulan sekali maupun setiap tahun sekali para PNS sangatlah peduli dengan kewajiban mereka untuk menyisihkan sebagian dari harta mereka untuk membayarkan zakatnya dari profesi atau pekerjaanya sebagai pegawai yang dibayar oleh Negara.

Para PNS muslim Sumbawa menyalurkan hartanya dalam berzakat sebagai motivasi mereka dari kewajiban mereka kepada Allah SWT yang sudah ada hukumnya dalam Al-Qur'an, dan zakat juga merupakan rukun Islam yang ketiga. Sebagai kewajiban yang harus dilaksanakan, mereka juga berfikir dari harta yang mereka miliki merupakan sebagiannya ada hak untuk orang-orang fakir miskin yang lebih membutuhkan.

Penulis mendasarkannya pada Al-qur'an dalam surat AdzDzariyat: ayat 19 yang berbunyi: 
Artinya: Dan pada harta-harta mereka ada hak untuk orang miskin yang meminta dan orang miskin yang tidak mendapat bagian. (AdzDzariyat: 19)

Dalam ajaran Islam disebutkan bahwa zakatnya rumah adalah menjamu tamu. Ajaran ini bisa dikembangkan misalnya, zakatnya mobil pribadi adalah sekali-sekali mengantarkan tetangga yang membutuhkan angkutan. Begitulah seterusnya sehingga pada setiap harta, disadari bahwa di dalamnya ada hak orang lain.

Kelebihan zakat dalam Islam adalah sebuah ibadah individual sekaligus sosial. Karena zakat profesi memotivasi para PNS muslim dalam kesadaran diri terhadap kewajiban kepada agama dengan menyisihkan sebagian dari harta untuk orang lain yang lebih membutuhkan, yang mana dalam penyaluran zakat itu sendiri dapat membantu masyarakat lain yang lebih membutuhkan. Karena zakat sendiri merupakan sebuah solidaritas sosial, tradisi tolong menolong sesama muslim dan sesama umat manusia.

Jadi, kewajiban zakat yang mereka keluarkan adalah untuk membersihkan harta mereka yang mereka anggap masih kotor yang tercampur dari hak-hak orang lain yang lebih membutuhkan dari gaji yang diterima setiap bulannya, selain itu juga merupakan suatu kepedulian sosial dalam hal tolong menolong antar sesama umat manusia.

\section{Analisis Pola Pembayaran Zakat Profesi}

Telah diuraikan dalam pembahasan sebelumnya tentang pola pembayaran zakat profesi yang mana para responden lebih banyak membayarkan zakat profesinya secara langsung kepada yang berhak dari pada melalui BAZ/LAZ. Dengan berbagai alasan, baik itu karena disekitar mereka masih banyak yang lebih membutuhkan untuk menerima zakat ataupun karena kendala malas mengurusi ataupun terlalu jauh untuk pergi ke BAZ/LAZ.

Dalam penyalurannya, sebagian dari para PNS di kantor mereka ada potongan untuk zakat, infaq, dan shodaqoh setiap bulan dari gaji yang mereka terima, tetapi dari penulis yang penulis ketahui hampir sebagian besar dari mereka meskipun di kantor ada potongan untuk zakat, mereka juga mengeluarkan zakat di luar (kantor), meskipun sebagian di kantor mereka juga didatangi oleh petugas dari BAZ/LAZ 
untuk menawari para PNS yang ingin berzakat melalui badan atau lembaga penyalur zakat tersebut.

Maka penyerahan zakat terserah kepada muzakki (orang yang berzakat), dalam hal ini aparat pemerintahan ataupun BAZ/LAZ tidak berhak untuk memaksa, karena membayar zakat adalah suatu kesadaran diri. Para PNS muslim yang juga sebagai Muzakki bisa memilih antara menyalurkan sendiri kepada para mustahiq atau dipercayakan kepada pihak manapun (termasuk bendahara PNS di kantor, BAZ,/LAZ, atau yayasan lain yang mengurusi zakat) yang bersedia menyalurkannya secara amanah dan profesional.

Penulis menyadari bahwa seluruh komponen dalam zakat (baik orang yang berzakat, penyalur zakat maupun penerima zakat) nanti di akhirat kelak akan dimintai pertanggungjawabannya, tentulah masingmasing yang bersangkutan akan memenuhi hak dan kewajibannya masing-masing secara profesional.

Disamping itu dalam kitab-kitab fiqh pelaksanaan zakat sudah dianggap sah bila telah memenuhi rukun atau unsur-unsur dan syaratsyarat yang telah ditentukan dalam hukum Islam. Adapun rukun dalam unsur-unsur yang harus terpenuhi dalam mengeluarkan zakat, unsur-unsur tersebut adalah:

1. Orang yang mengeluarkan zakat (muzakki)

2. Harta yang wajib dizakati

3. Penerimaan zakat (mustahiq)

4. Amil

Selain 4 unsur di atas diperlukan juga syarat-syarat zakat yang lain, yaitu sebagai berikut:

1. Syarat Orang yang Mengeluarkan Zakat

Orang yang wajib mengeluarkan zakat adalah orang atau badan yang dimiliki oleh orang muslim yang berkewajiban menunaikan zakat apabila memiliki kelebihan harta yang telah cukup haul dan nishabnya

2. Syarat harta yang dizakatkan

a. Pemilikan yang pasti, halal dan baik.

b. Berkembang

c. Melebihi kebutuhan pokok

d. Bersih dari hutang

e. Mencapai nisab 
f. Mencapai masa haul

3. Syarat penerimaan zakat meliputi 8 asnaf

a. Orang fakir: orang yang amat sengsara hidupnya, tidak mempunyai harta dan tenaga untuk memenuhi penghidupannya.

b. Orang miskin: orang yang tidak cukup penghidupannya dan dalam keadaan kekurangan.

c. Pengurus zakat: orang yang diberi tugas untuk mengumpulkan dan membagikan zakat.

d. Muallaf: orang kafir yang ada harapan masuk Islam dan orang yang baru masuk Islam yang imannya masih lemah.

e. Memerdekakan budak: mencakup juga untuk melepaskan muslim yang ditawan oleh orang-orang kafir.

f. Orang berhutang: orang yang berhutang karena untuk kepentingan yang bukan maksiat dan tidak sanggup membayarnya. Adapun orang yang berhutang untuk memelihara persatuan umat Islam dibayar hutangnya itu dengan zakat, walaupun ia mampu membayarnya.

g. Pada jalan Allah (sabilillah): yaitu untuk keperluan pertahanan Islam dan kaum muslimin. Di antara mufasirin ada yang berpendapat bahwa fisabilillah itu mencakup juga kepentingan-kepentingan umum seperti mendirikan sekolah, rumah sakit dan lain-lain.

h. Orang yang sedang dalam perjalanan yang bukan maksiat mengalami kesengsaraan dalam perjalanannya. (Abdul Ghofur, Anshori, 2006: 25-29)

Kalau melihat unsur-unsur dan syarat-syarat di atas, bahwa pelaksanaan zakat profesi pada para PNS yang ada di Sumbawa secara umum sudah sesuai dengan hukum Islam, karena telah memenuhi unsur dan syarat di atas. Akan tetapi para PNS di Sumbawa dalam penyaluran zakat tidak semuanya melalui lembaga amil zakat atau badan amil zakat yang ada di kota Sumbawa, namun kebanyakan dari responden yang penulis wawancarai mereka membayarkan zakat profesinya secara langsung kepada mustahiq zakat, yaitu para fakir miskin yang berada di dekat rumahnya ataupun yang masih saudara mereka sendiri yang kurang mampu. 
Tetapi penulis ingin penyimpulkan bahwasanya para PNS yang ada di Sumbawa, mereka mengeluarkan $2.5 \%$ dalam membayarkan zakat profesinya, tetapi juga ada yang lebih dari $2.5 \%$, karena zakat profesi yang mereka keluarkan sebagian ada yang bercampur dengan harta dari pekerjaan lain, dan juga dari zakat profesi tersebut yang mereka terima ada potongan juga dari kantor mereka yang dikhususkan untuk infaq dan zakat. Jadi, di penulis beranggapan dari $2.5 \%$ yang mereka keluarkan sebagian mungkin bisa jadi lebih, mungkin juga bisa kurang, karena beberapa faktor seperti sudah adanya potongan gaji untuk zakat, kurangnya pencapaian nisab karena kebutuhan yang lebih, dan lain-lain masalah yang ada yang memaksa mereka untuk tidak membayarkan zakat profesinya dengan tepat.

Teknik penentuan nisab dalam setiap jumlah pendapatan atau penghasilan yang diterima dari seorang PNS yang mencapai nisab seperti gaji yang tinggi dan honorarium yang besar, serta pembayaranpembayaran yang besar kepada para golongan profesi, wajib dikenakan zakat, sedangkan yang tidak mencapai nisab tidak terkena. Ini dapat dibenarkan, karena membebaskan orang-orang yang mempunyai gaji yang kecil dari kewajiban zakat dan membatasi kewajiban zakat hanya atas pegawai-pegawai tinggi dan tergolong tinggi saja. Ini lebih mendekati kesamaan dan keadilan sosial.

Pada hakikatnya zakat merupakan instrumen yang penting dalam meningkatkan ekonomi Islam serta merupakan sumber kekuatan dalam mengentaskan kemiskinan dan meningkatkan kualitas kehidupan umat manusia. Kesadaran berzakat memang menjadi tolak ukur ketaatan seseorang terhadap kewajiban atas agamanya.

\section{KESIMPULAN}

Zakat profesi dalam Islam pada hakikatnya adalah zakat yang dikeluarkan dari hasil profesi (pekerjaan) seseorang, baik Dokter, Dosen, Guru, Kepala Sekolah, Karyawan, dan lain-lain, yang gajinya dibayar oleh pemerintah, dan telah cukup nisabnya untuk dibagikan pada para mustahiq zakat. Dalam undang-undang Nomor 38 tahun 1999 tentang pengelolaan zakat dalam pasal 1 ayat (2) dikatakan bahwa zakat adalah harta yang wajib disisihkan oleh seorang muslim atau badan yang dimiliki oleh orang muslim sesuai dengan ketentuan agama untuk diberikan kepada yang berhak menerimanya. Dalam 
pasal 11 ayat (2) huruf (f) dikatakan bahwa hasil pendapatan dan jasa merupakan salah satu harta yang dikenai zakat.

Dari pemahaman masyarakat muslim PNS di Sumbawa tentang pembayaran zakat profesi $75 \%$ responden dari 20 orang responden mengaku paham dengan pengertian zakat profesi, dengan berbagai alasan sosial keagamaan ataupun kondisi dari keuangan dalam kecukupan kehidupan sehari-harinya untuk menyisihkan sebagian hartanya dalam memenuhi kewajiban mereka sebagai PNS untuk membayar zakat profesi.

Dari $40 \%$ responden yang penulis ambil dari 20 orang responden, yang memotivasi mereka untuk membayar zakat profesi adalah kepedulian mereka sebagai seorang muslim yang baik terhadap kewajiban agama, dan 30\% masing-masing sisanya adalah solidaritas sosial/tolong menolong dan agar hartanya menjadi barokah, karena pada hakikatnya dari harta mereka itu ada hak untuk orang lain. Jadi yang memotivasi masyarakat PNS di Sumbawa dalam membayar zakat profesi merupakan kewajiban agama dan kepedulian sosial antar sesama umat manusia.

Dari pola pembayaran zakat Profesi para PNS muslim di Sumbawa, 90\% responden dari 20 orang responden membayarkan zakat profesinya secara langsung kepada yang berhak dari pada melalui BAZ/LAZ atau membayarkan pada Yayasan lainnya, dari 20 orang responden rata-rata lebih merasa mantap hatinya dengan cara menyalurkan zakat profesinya secara langsung kepada yang berhak, terutama para tetangga atau bahkan saudara mereka sendiri yang membutuhkan.

\section{DAFTAR PUSTAKA}

Al-Zuhayly, Wahbah. (1995) Zakat Berbagai Kajian Mahzab, Terjemahan Agus Efendi. Bandung: Remaja Rosda Karya Offset.

Anhar Moh, Mulyawan Aris dan Pusdok Sm-77. Potensi Zakat Rp 9,3 Triliun, Suara Merdeka Edisi 31 Agustus 2009.

Ghofur, Anshori Abdul. (2006). Hukum Dan Pemberdayaan Zakat. Yogyakarta: Pilar Media.

Hafidhuddin, Didin. (2002). Zakat Dalam Perekonomian Modern. Jakarta: Gema Insani.

Hasan, Alwi. (2007). Tim Redaksi Kamus Besar Bahasa Indonesia Edisi Ketiga. Jakarta: Balai Pustaka. 
Masri, Singarimbun dan Effendi Sofian. (1983). Metode Penelitian Survai. Lembaga Penelitian, Pendidikan Dan Penerangan Ekonomi Dan Sosial.

Moloeng, Lexy J. (2004). Metode Penelitian Kualitatif. Bandung: Rosda.

Mufraini, M. Arif. (2006). Akuntansi Dan Manajemen Zakat. Jakarta: Kencana Prenada Media Group.

Muhibbin, Bagaimana Agar Konsisten, Suara Merdeka Edisi 31 Agustus 2009.

Qardawi, Yusuf. Hukum Zakat. Jakarta: Litera Antarnusa. 1973.

Sayyid, Sabiq. (1978). Fikih Sunnah 3. Bandung: Al-Ma'Arif.

Suharsimi, Arikunto. (1997). Prosedur Penelitian Suatu Pendekatan Praktek. Jakarta: Rineka Cipta.

Syahhatih, Ismail. (1987). Penerapan Zakat Dalam Dunia Modern. Pustaka Dian: 1987

Sumbawa Dalam Angka Tahun 2006. (2007). Badan Pusat Statistik Nusa Tenggara Barat (NTB).

Suyitno, Junaidi Heri, dan Abdushomad M. Adib. (2005). Anatomi Figh Zakat. Lembaga Kajian Hukum Islam (LKHI) Fakultas Syariah IAIN Raden Fatah Palembang, Pustaka Pelajar. 